\title{
Polystylism in the context of Postmodern Music. Alfred Schnittke's Concerti Grossi
}

\author{
MIHAELA-GEORGIANA BALAN, Assistant Professor, PhD \\ "George Enescu" National University of Arts Iaşi \\ ROMANIA*
}

\begin{abstract}
One of the multiple orientations of the musical postmodernism is polystylism - a concept used and theorized by the Russian composer and musicologist Alfred Schnittke. He identified its specific techniques in previous academic tradition and organized its principles by writing many essays, papers and by applying these compositional methods in his own work. The approach of polystylism offers the opportunity to observe artistic phenomena in a synthetic perspective and to understand the compositional methods by which tradition is still revalued in some directions of the postmodern period. This paper deals with the problems encountered in the research on this subject, the lack of this term in the dictionaries, the political and cultural context when polystylism was introduced, the tendency to consider unorganized and unoriginal those works based on quotes, previous writing techniques and musical languages, traditional genres or structures and therefore, the perception of some musicians to underestimate Schnittke's talent and mastery as a composer.
\end{abstract}

Keywords: postmodernism, polystylism, quotation, allusion, adaptation.

\section{Introduction}

Polystylism, known in modern musicology as one of the most representative directions of the musical postmodernism, is frequently associated with the name of composer Alfred Schnittke, who theorized this concept in 1971 and imposed it in the musical field as a genuine compositional principle. Using it systematically in his own creations, Schnittke was a follower of the retrospective artistic orientation, choosing to use techniques of recovery and revaluation of the musical tradition, along with other sources such as folklore, jazz and entertainment genres, from his own perspective at the end of the $20^{\text {th }}$ century.

The approach of polystylism in a scientific research is surprisingly difficult, due to the limited resources related to this concept. A simple search of the term in the specialized dictionaries raises question marks from the first phase of concern for this topic, as the notion is not present either in the New Grove Dictionary of Music and Musicians, or in the Romanian dictionaries of musical terms, or in the Explanatory Dictionary of the Romanian Language. However, the contact with some teachers and students who were related to the East-European school environment and the search of the term in the Russian-

\footnotetext{
*mihaela.balan2015@gmail.com
} 
language music resources indicate a broader concern about polystylism in the former Soviet Union.

The discovery of this discrepancy in the interest given to this subject determines us to approach the problem as a scientific research in which we could analyze the premises of the phenomenon, the theoretical marks, the compositional applications and the didactic aspects when approaching polystylism. When searching the musical materials of interest in this matter, we noticed some papers, books from the North American, Western and CentralEuropean areas that reach the problem of polystylism, directly or tangentially, by analysing the most important directions of the postmodernist musical aesthetics since the 1970s: Ivan Moody - The Music of Alfred Schnittke (1989); Irinel Anghel - Orientations, Directions, Tendencies of Romanian Music in the Second Half of the Twentieth Century (1997); Gavin Thomas Dixon Polystylism as Dialogue: a Bakhtinian Interpretation of Schnittke's Symphonies No. 3, 4 and his Concerto Grosso No. 4/ Symphony No. 5, PhD Thesis (2007); Jean-Benoit Tremblay - Polystylism and Narrative Potential in the Music of Alfred Schnittke, PhD Thesis (2007); Oana Andreica - Alfred Schnittke's Polystylistic Journey: the Third String Quartet (2012); Oleg Garaz - Postmodern Music: Reinventing Musical Art after the End of Modernity (2012); Graham Freeman - Alfred Schnittke and the Language of Trauma (2013); Courtney Sangis - Alfred Schnittke on Polystylism. Some of Schnittke's thoughts on Polystylism in music extracted and analyzed (2016).

\section{Theoretical marks for the contextualization of polystylism as an aesthetic orientation in postmodern music}

Any discussion regarding polystylism should begin with the historical and artistic framing of the concept in the larger spectre of postmodernism - a stage in which the current world is considered to have entered, according to the historical systematizations made by theorists from all fields, literary or art critics. Thus, postmodernism begins with an approximation of the seventh decade of the last century and reaches up to the present, having features that lead the debate further, towards a music of the future. The transition from modernism to postmodernism was approached in the theories of great thinkers of the twentieth century, such as Theodor Adorno, Jean-François Lyotard, Jürgen Habermas, who outlined the philosophical and sociological coordinates of the phenomenon of transition through observations targeting evolution and the transformations of society in the last century, the individual and collective psychology of the cultures, the inter-influence of radical and neutral-moderate movements. Therefore, a change of general perception and mentality was noticed, by shifting the attention from the introduction and acceptance of the new to the observation and acceptance of pluralism of ideas, of cultural diversity, as 
an expression of the strongly desired universal democracy. The political emancipation acquired by more and more countries will allow the fulfilment of humanity's highest aspiration - freedom of expression. Some features that could synthesize the essence of postmodernity (both aesthetically-culturally and existentially-empirically) are diversity, versatility, heterogeneity, eclecticism.

Postmodernism is still a source of questions and dilemmas for many researchers, as the transition from the modern to the postmodern era took place without the actual awareness of the transition from one stage to another, and also because this period has not ended yet. Therefore, it is difficult to draw conclusions at this moment of the history in order to have a complete and systematic image of current phenomena. An essential idea about how history is generally approached belongs to the literary critic, political theorist and American philosopher Fredric Jameson, who expresses doubt about the systematization of human thinking over time by focusing on unitary criteria, which deal with common issues, generalizing features of a period, without giving too much importance to secondary features or other characteristics, determining (as he calls them in his paper) the "theory of stages" or "teleological historiography". However, Fredric Jameson emphasizes that these philosophical, cultural, artistic movements, theorized by the norms of linear history, "tend to obliterate difference and to project an idea of the historical period as massive homogeneity (bounded on either side by inexplicable 'chronological' metamorphoses and punctuation marks). This is, however, precisely why it seems to me essential to grasp 'postmodernism' not as a style, but rather as a cultural dominant: a design that allows for the presence and coexistence of a range of very different, yet subordinate features" (Jameson, 1984, pp. 55-56).

Talking about postmodern music at a general level, we start from the idea that it does not impose stylistic norms, does not propose as an aesthetic purpose the production of an avant-garde-like impact, nor the intention of recovering certain movements from the musical past, having rather a free, permissive and selective approach of the most suitable artistic means, in order to express the message pursued by the composer. In other words, the creator of postmodern music is able to use any genre, form, construction, sound language, writing technique, without being constrained by the urgent need for unity, continuity, structural logic and reconciliation of contrasts. On the contrary, postmodern music might include contradictions, fragmentations, dislocations, unexpected juxtapositions, whose consistent appearance within the artistic discourse outlines a genuine aesthetic norm. One may discuss about an aesthetics of the rupture, whereby the author of the discourse creates intentional discrepancies, not by radical denial, but by integration of the past into the present, in different contexts and with different effects (surprise, praise, commemoration, irony, parody, etc.). These features are formulated on the basis of the theoretical 
synthesis made by the American musicologist Jonathan D. Kramer (Kramer, 1996, pp. 21-22).

When searching for a possible definition of the postmodern music, we stopped at the observations made by Valentina Sandu-Dediu, the author of the homonymous article in the (Romanian) Dictionary of Musical Terms, where many essential aspects are exposed and questioned. One of the main issues is the ambiguity of the terminological significance, determined by the contradictory status of contemporaneity, induced by the multiple divergent orientations, by "the typological multiplicity of thinking of the last decades" and also by "different creators who could be stylistically unified through postmodern coordinates, without being able to consider them postmodern composers in their entirety" (Sandu-Dediu, coord. by Gh. Firca, 2008, p. 443).

Another perspective on this complex phenomenon is formulated by the musicologist Oleg Garaz, author of an extensive and elaborate article in the Romanian publication Muzica: "Musical postmodernism reformulates the image of suggestive efficiency, [...] offering a new conception of accessibility by formulating a third type of addressability (author's emphasis) with almost exclusive stake on referentiality. The significance of these criteria addressability and referentiality (in their postmodern meaning), could be 'read' through the grid of a postmodern phenomenon such as suppressing the boundaries between scholarly and popular cultures, but with a pronounced tendency to return to the vernacular" (Garaz, 2012, p. 12).

In many conferences of the last decade, as well as in the specialized media (music studies, music criticism magazines, radio programs), we have noticed the frequent use of terms and phrases such as "stylistic poop", "hyperstyle", "meta-style", which reflect the artistic reality of our day, characterized by fragmentation, mosaic, crossbreeding, pop-art. In the field of music, some techniques were used long before postmodernism, because quotation, paraphrase and collage are known from the beginning of the 19th century. However, the diversity of inspiration sources, of musical language features, of sound means (either natural or technological) and aesthetic directions has reached a historical peak, with the highest density of traditional and avantgarde orientations. Compound terms, such as: poly-rhythm, poly-metrics, polytonality, poly-modalism, poly-semantics, became increasingly necessary. Thus, the appearance of polystylism was somehow natural in the context of the 20th century, referring to the combination or insertion of several styles, writing techniques and sonorous languages in a single work. Although such processes can be recognized in the works of composers from previous eras, polystylism has been systematically approached on theoretical and compositional levels since 1971, through the manifesto-essay signed by Alfred Schnittke, entitled "Polystylistic Tendencies in Modern Music". 
Initially entitled the "new eclecticism", the artistic movement that Schnittke identified in theory could be recognized in musical works through two important techniques, that were exposed in his essay: quotation and allusion. Both categories already existed in musical practice since the period of musical Romanticism, but there are also other means whose status is not clear from the perspective of the Russian composer.

a. When referring to the use of genres, forms and writing techniques, quotation is considered by Schnittke as a way of using a certain style from a previous artistic movement, besides taking a melodic theme, a harmonic sequence, etc. In this case, we should mention the use of musical techniques and language elements that were specific to pre-classical music in the works of later composers, even during Classicism. Another way to relate to a previous model is adaptation, which Schnittke includes in the theoretical sphere of the quotation, due to the intentional reference to a particular composer or style. Also, a particular result of quoting several musical sources is the collage, a technique inspired from visual arts that generates works with mixed content, with variable structure and specific musical language, adapted to the area of inspiration.

b. On the other hand, the allusion from Schnittke's paper, understood as the use of musical language features or writing methods reminiscent from another composer's style, it may be related to composition techniques theorized in Western (and also Romanian) musicology, analysing the degree of nearness or vicinity to the original model: creation in a certain style, mannerism, stylization, parody, pastiche. Therefore, the style can be approached with an objective, neutral attitude, without implying a certain reaction from the composer's perspective or, on the contrary, it can have a semantic content or attitude (nostalgia, homage, humour, irony), which can be deducted behind the style displayed by the composer.

The most important aspects that we keep in mind about the use of polystylism in postmodern aesthetics are the integration of inspirational elements with different origins, the neutral attitude towards the continuation or denial of modernism. Polystylism allows orientations in both directions and often has a ludic approach of elements from other traditions, genres and musical practices. The artistic result of postmodern music ranges from the typical abstract sonorities of avant-garde to the mix of techniques and fragments of familiar, known music, without hierarchical differences between modern styles of the twentieth century and those restored from previous centuries, without differentiation between academic and folkloric music, between the artistic creation considered elitist, of high level, and the culture of the ordinary population. 


\section{General and particular aspects of polystylism in Alfred Schnittke's compositional and theoretical perspective}

Although considered a composer pertaining to the generation of artists who were restricted, influenced and ideologically controlled by post-World War II Soviet policy, Alfred Schnittke made his own destiny through 20th century Russian history, his own creative universe, artistic style and musical career. Frequently associated with Dmitri Shostakovich, Gustav Mahler, Alban Berg and even Charles Ives or Luciano Berio, Schnittke has not become an epigone of them, even though certain connections could be made with their compositional manner and their aesthetical view based on irony, parody and eclecticism. In the first half of the last century, there had already been composed many scores as war testimonies, works that confronted the harsh living conditions of the artists by subtle artistic means and encrypted musical language. Schnittke was also affected by this context, but he should not be considered a politically dominated composer, because he did not perceive himself from the tragic perspective of powerlessness. On the contrary, he sought solutions in order to revaluate his creative talent and ideas.

Schnittke proceeded from the aesthetic premises of duality, ambiguity, irony, grotesque, in a similar manner to his Russian and Western European predecessors, but he intended a broader stylistic sphere, looking further on spatial and temporal levels. The aesthetics behind his creation is based on a confrontation of contrasts (which reminds us of Romanticism) between distant stylistic areas and very different compositional techniques. As we have noticed in the general philosophy of postmodernism, Schnittke transcends the boundaries of binominal antinomies (national-universal, particular-general, real-unreal, subjective-objective, individual-society), aiming at a plurality of experiences, meanings, interpretations. His polystylism is not just a medley of styles, but a coherent integration, a recontextualization of quotations, manners, artistic techniques within a diverse, heterogeneous and even chaotic sound world. His goal was to create a different order in the musical universe of the second half of the last century, by trying to comprise the essence of music in all its stages, in a fascinating stylistic journey. In other words, he had the endeavour to carry on the artistic ideal expressed by the Beethovenian and Mahlerian symphonies of embracing the world. Schnittke "represents not only a moment in the history of Russia, but also a moment in the history of music" (Ross, 1992, web source).

Polystylism is a very suggestive hypostasis for the metaphorical image of the postmodernism as a polymorphic conglomerate structure, by revaluating the styles and means available up to that moment as a genuine principle of creative "democracy" - the aspiration of artists from Eastern Europe. When analysing Schnittke's work, we cannot discuss about freedom itself, although polystylism creates the superficial appearance of this artistic independence. For 
Schnittke, it was the key to his own release, which subsequently opened the perspective of his own musical identity at European and universal level.

Alexander Ivashkin, one of the most prominent biographers and analysts of Schnittke's life and work, is also a well-known musicologist of the Russian musical culture, writing about it that "to a Russian composer, music is not a text, not a construction; it is a special kind of reality. Music emerges in organic juxtapositions of important elements, rather than in a mechanical, strictly logical development of the main theme or idea. Simple elements play a very important role in the symphonies of Schnittke, Gubaidulina, Kancheli, Silvestrov, Tishenko. Those elements, in different contexts, practically organize the musical form, becoming points of orientation in the flow of different and contrasting events. The spaces (and the time) in Soviet music of the 1970s and 1980s are living, real spaces, not just abstractions" (Ivashkin, 1992, p. 555).

Although often interpreted as a manifestation of nostalgia for the past, his music was not composed with this intention, as the composer himself stated in some of the interviews that he has offered in the latter part of his life. The overcoming of deeply internalized traumas proves his creative force, leading to his particular attitude of irony, pastiche and alienation, which should not be interpreted as contemplation of sorrow or madness in the pathological sense, because they are rather processes of transcending the concrete reality through artistic language. The techniques of quotation and allusion are not evidence of a melancholic return on the paths of history, having rather the intention to express homage and respect for the previous composers, to create sonorous syntheses of the musical styles, to reflect the reality of an inconstant world and full of contradictions, but also a way of gaining a different creative freedom within the Soviet communist system, avoiding the forbidden techniques. Therefore, polystylism is not a manifestation of retrospective nostalgia, but a sublimation of his suffering into the recovery and revitalization of memory in its collective, historical sense.

Therefore, in order to define and comprehend polystylism, it is necessary to establish the contexts to which it is applied and referred:

- Polystylism can be traced as an artistic phenomenon back to the XVIXVII centuries, by listening and analyzing works of composers who incorporate several stylistic stages $^{1}$, by assimilating the previous tradition and the integration of existing styles in their time of life in their works. This is a natural process in each artistic period, highlighting the specific

\footnotetext{
${ }^{1}$ For example, C. Monteverdi, who used both prima prattica and seconda prattica, J. S. Bach who composed by using counterpoint in both stile antico and stile moderno; later, W. A. Mozart and L. van Beethoven continued to make use of these traditional writing techniques, inherited from Baroque; in the nineteenth century, composers inserted musical quotes and melograms in their works and wrote variational cycles or paraphrases based on a musical material taken from other sources.
} 
style/styles for each epoch, as well as the individual features at the compositional level.

- From a historical point of view, polystylism appears as a sui generis artistic direction in the second half of the $20^{\text {th }}$ century, having the general aesthetic characteristics of postmodernism, which are applied to the musical style. Thereby, the plurality of styles represents a reflection of the postmodern era, a synchronous manifestation of the multiple aesthetic hypostases that musical art has acquired over time, having the potential to create syntheses and antitheses, stylistic analogies and pastiches.

- In the context of Alfred Schnittke's compositions and musicologic activity, polystylism is an aesthetic option that he has voluntarily and consciously chosen, after having had experienced the new, the modern, the avant-garde. He proved the ability to balance previous radical movements by using existing techniques and means, which he identified as an autonomous stylistic orientation and theorized under the extensive umbrella of this term.

- A less objective approach to polystylism concerns the position of the man and creator A. Schnittke in the context of his time, a period that was still affected by the consequences of the two world wars, causing a profound transformation of the artists' psychology. From this perspective, Schnittke's music suggests the intention of a unifying reconciliation between objective and subjective, past and present, collective cultural movements and individually felt effects.

The systematization of these aspects creates an overview of the motivation behind the stylistic choices made by Schnittke, helping us to understand his music better, both in the context of the time in which he lived and the times he quoted, stylized and recreated.

\section{The analysis of musical language elements that are relevant for the evolution of polystylism in the concerto grosso genre from A. Schnittke's works}

Alfred Schnittke's figure in the context of musical directions from the 20th century has influenced the evolution of certain traditional genres and musical techniques by approaching and transforming the concerto grosso genre according to his own aesthetic view, as well as by creating a fusion between apparently irreconcilable styles, without going too far into the extremes of hyper-complexity or opposite directions, such as minimalism, pointillism, new simplicity. The result of his work is a spectacular journey in time, in which themes, motifs, melograms or sonorities of previous styles are engaged and reinterpreted from the perspective of techniques and textures conceived by the composer as if that music were first created in the postmodern age. In an autoironical presentation, Schnittke describes his concerts as "utopian", due to the 
stylistic mismatch between entertainment music (which was considered banal, ordinary) and "serious" music (academic musical traditions).

In order to observe and discuss the essential aspects of the evolution of the concerto grosso genre in Schnittke's compositional thinking, we made a synthesis of the features in his six Concerti Grossi and also in the Triple Concerto - the last work of the kind in his creation, named differently due to the changes that have occurred over time in the compositional process of the genre. The years of work indicate a late approach of this genre: the first Concerto Grosso was composed at the age of 43 (1977) and the Triple Concerto at 60 (1994). Therefore, one can perceive these works as a result of his mature perspective, with a constant deepening and return to this genre until the end of his life (in 1998).

When analysing the instrumental and orchestral structure of the six Concerti Grossi and the Triple Concerto, we observe a great diversity of timbre "palette" chosen by the composer for each creation, ranging from associations close to Baroque music (woodwind instruments, harpsichord, string orchestra) and up to the insertion of typical instruments for the 20th century, either in the soli group or in the tutti ensemble (prepared piano in the first concerto; electric guitar, drum kit, brake drum in the second concerto; celesta in the third concerto). Such juxtapositions create strong contrasts, in which the instruments become representative "voices" of certain styles, leading either to the collision between several artistic worlds, or to the attempt to reconcile these oppositions and adjoin them into a globalized, integrative conception.

In terms of the structure of the genre, Schnittke started from a composition in several movements, with variable number (first concerto - six movements, second concerto - four movements, third concerto - five movements), a feature that can be compared with the different structure of the concerti grossi during the Baroque age. The last three concerti grossi from Schnittke's creation, as well as the Triple Concerto, have in common a more concise manner of thinking, prevailing the structure in four movements (the only work with three sections is Concerto Grosso no. 6), but without keeping a consistent sequence of tempo. If the genre is characterized by the tendency to restrict the number of movements and the diversity of the musical material used by the composer, in terms of formal thinking, it evolves from a rigorous organization of sections based on motives, themes, distinct language elements that can be dissociated and individualized, towards a free development, with indefinite forms, which builds up throughout the unfolding of the sonorous discourse.

After his first stroke in 1985, Schnittke had a stagnation period, after which his compositions became less rigorous, with hybridized genres and forms, as it happens in Concerto Grosso no. 4, which is entitled by Schnittke himself Symphony no. 5, indicating a bivalent work, with four movements, 
similar to the compositional manner in the symphonic music by Gustav Mahler. The last concerti grossi are characterized by the renunciation of quotations, the adoption of a more personal style, the insertion of deeper meditative sections, insisting on a certain timbre or category of instruments, with a less emphasized rhythm, sometimes generating the impression of a temporary suspension.

The syntaxes approached by Schnittke are very diverse, ranging from simple melodic exposures, such as genuine melodies, to very dense, overloaded areas with massive sonorous effects. However, an essential feature remains the polyphonic technique, which can be found in his concerti grossi both in imitative and non-imitative hypostases, through the linearity of the levels, the pre-classical figuration, the polyphony of attacks, the superposition of themes and fragments in different styles, textural effects. The fast alternation of agglomerate moments with rarefied sections generates discontinuance, rupture within the musical discourse, but, when seeking the general dramaturgy, a particular unity is generated through the stylistic consistency specific to certain fragments and the compositional techniques inside the work. After the second stroke of 1992, tradition becomes a distant echo for Schnittke, a sublimated background on which original ideas, contrasting musical lines and textures, free evolutions, with diffuse structural and temporal marks are projected. These elements offer a different perception of the whole inside the last concerti grossi than the first three works of the same genre.

In the following tables, these features can be observed in a systematic way, due to the organization based on some general criteria that highlight the particularities of genre, structure, style for the previously mentioned works. 


\begin{tabular}{|c|c|c|c|c|}
\hline Work/Title & $\begin{array}{c}\text { Year of } \\
\text { composition }\end{array}$ & $\begin{array}{c}\text { Solo ins trume nts/ } \\
\text { orches tral } \\
\text { ensemble }\end{array}$ & $\begin{array}{l}\text { Genre structure in } \\
\text { movements }\end{array}$ & Ge ne ral stylis tic obs ervations \\
\hline $\begin{array}{l}\text { Concerto Grosso } \\
\text { No. } 1\end{array}$ & 1977 & $\begin{array}{l}2 \text { violins, prepared } \\
\text { piano, harpsichord } \\
\text { and } 21 \text { strings }\end{array}$ & $\begin{array}{l}\text { I. Preludio. Andante } \\
\text { II. Toccata. Allegro } \\
\text { III. Recitativo. Lento } \\
\text { IV. Cadenza } \\
\text { [without tempo } \\
\text { indication] } \\
\text { V. Rondo. Agitato } \\
\text { VI. Postludio. } \\
\text { Andante-Allegro-- } \\
\text { Andante }\end{array}$ & $\begin{array}{l}\text { - Baroque canonic manner in the evolution of the } \\
\text { musical discourse, with Vivaldi violin-like sections, } \\
\text { insertion of the B-A-C-H melogram. } \\
\text { - Mozart and Beethoven features, by using motives } \\
\text { with developping potential. } \\
\text { - atonalism, serialism, avant-garde elements alternating } \\
\text { with previous stylistic sections. } \\
\text { - Brahms Hungarian Dances motives, Tchaikovsky } \\
\text { sonorities from his Violin Concerto, insertion of a } \\
\text { Tango theme. } \\
\text { - disruptive chords, fragmented discourse, unity given } \\
\text { by recurrence of themes and styles, final synthesis as } \\
\text { deconstruction of the previous movements. } \\
\text { - heterogeneous overall perception, thorough attention } \\
\text { to details, rigurous organisation. }\end{array}$ \\
\hline $\begin{array}{l}\text { Concerto Grosso } \\
\text { No. } 2\end{array}$ & $1981-1982$ & $\begin{array}{l}\text { violin, cello and } \\
\text { triple symphony } \\
\text { orchestra } \\
\text { (including electric } \\
\text { guitar, drum kit, } \\
\text { brake drum) }\end{array}$ & $\begin{array}{l}\text { I. Andantino. Allegro } \\
\text { II. Pesante } \\
\text { III. Allegro } \\
\text { IV. Andantino }\end{array}$ & $\begin{array}{l}\text { - distorted Silent Night theme, allusions to Bach } \\
\text { Brandenburgic Concertos, pop music interferences, } \\
\text { march rhythms. } \\
\text { - strong contrast between soli and tutti, between solistic } \\
\text { disc ourse and symphonic context, as a metaphor of } \\
\text { deeper antinomies: introspective-extrovert, individual- } \\
\text { collective, deep-shallow. - Baroque overall perception. }\end{array}$ \\
\hline
\end{tabular}




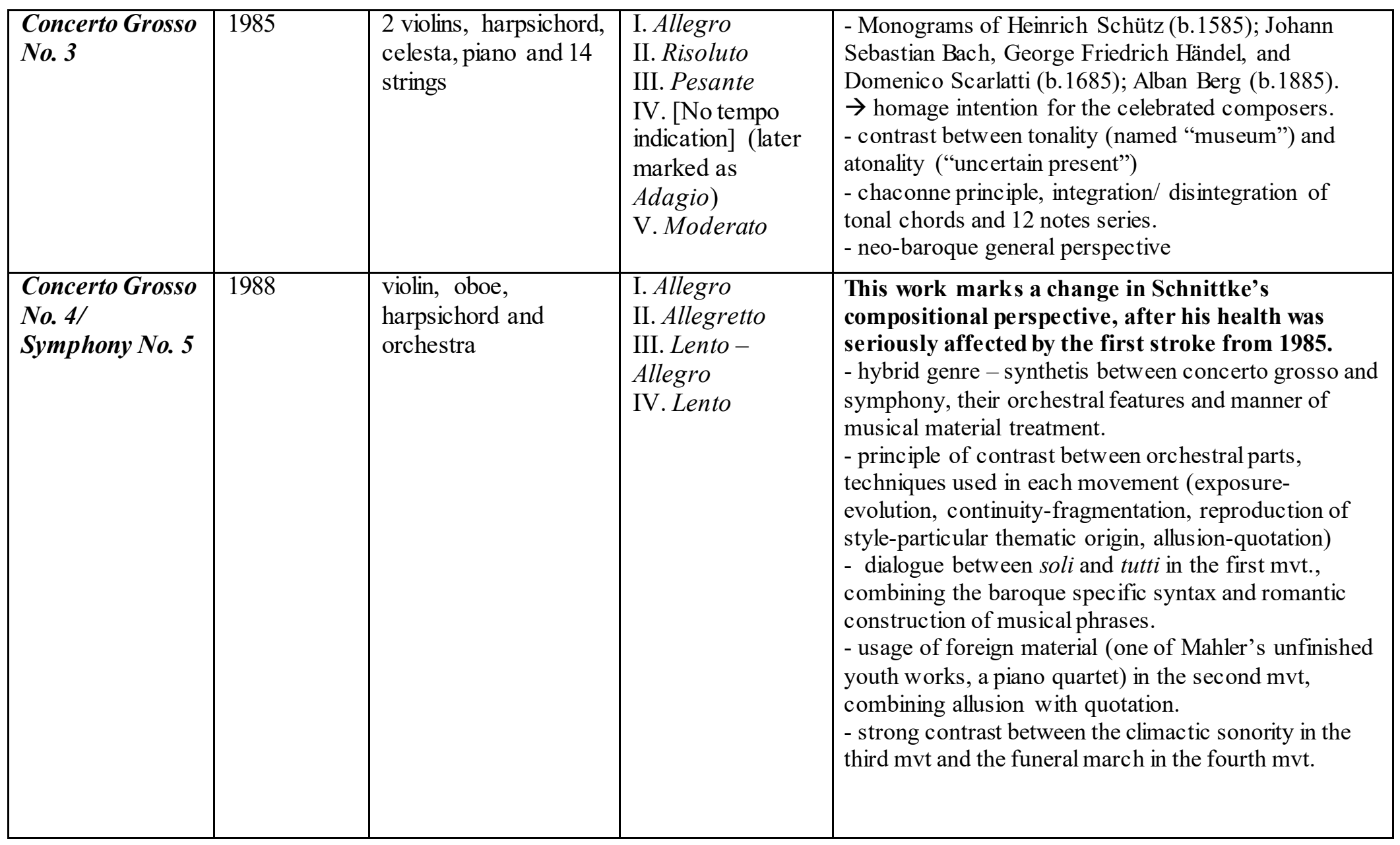




\begin{tabular}{|c|c|c|c|c|}
\hline $\begin{array}{l}\text { Concerto Grosso } \\
\text { No. } 5\end{array}$ & 1990-1991 & $\begin{array}{l}\text { violin, (offstage) piano } \\
\text { and orchestra }\end{array}$ & $\begin{array}{l}\text { I. Allegretto } \\
\text { II. Without tempo } \\
\text { indication } \\
\text { III. Allegro } \\
\text { IV. Lento }\end{array}$ & $\begin{array}{l}\text { - unlike the previous Concerti Grossi, this work is } \\
\text { different, without quotations or references to other } \\
\text { styles, offering a more personal approach. } \\
\text { - particular perception of the basso continuo, given by } \\
\text { the offstage position of the piano and the mixture of } \\
\text { timbres between harpsichord, harp, celesta and piano. } \\
\text { - particular configuration at the general structure level } \\
\rightarrow \text { it could be considered a cyclic work, due to a } \\
\text { rhythmic motive introduced in the first mvt. and } \\
\text { developed in each of the subsequent mvts. } \\
\text { - introverted expression, suggesting meditation, } \\
\text { solitude, suspension of time in the first and last mvts. } \\
\text { - use of the variation principle in the } 2 \text { nd and 3rd mvts, } \\
\text { giving a stronger pulse to the rhythmic configuration. }\end{array}$ \\
\hline $\begin{array}{l}\text { Concerto Grosso } \\
\text { No. } 6\end{array}$ & 1993-1994 & $\begin{array}{l}\text { piano, violin and string } \\
\text { orchestra }\end{array}$ & $\begin{array}{l}\text { I. Andante- } \\
\text { Allegro } \\
\text { II. Adagio } \\
\text { III. Allegro vivace }\end{array}$ & $\begin{array}{l}\text { - After his second stroke from 1992, Schnittke changed } \\
\text { even more his musical thinking, in terms of indefinit } \\
\text { forms and structures, leading to a constantly changing } \\
\text { discourse. } \\
\text { - a conc ise work, lasting around } 15 \text { min. } \\
\text { - slight features from older musical ages than previous } \\
\text { Concerti Grossi } \rightarrow \text { tradition is rather a distant echoe of } \\
\text { ancient times. } \\
\text { - fugal intention in the first mvt, due to immitation and } \\
\text { polyphony (used only occasionally) } \\
\text { - 2nd mvt. conceived as a static, stagnating moment of } \\
\text { meditation (for piano and violin exclusively) } \\
\text { - strong contrast between suspension of motion and the } \\
\text { outburst of the orchestra in the last mvt. } \\
\text { - general overview - prevalence of modern elements. }\end{array}$ \\
\hline
\end{tabular}




\begin{tabular}{|c|c|c|c|c|}
\hline $\begin{array}{c}\text { Work/ } \\
\text { Title }\end{array}$ & $\begin{array}{c}\text { Year of } \\
\text { compo- } \\
\text { sition }\end{array}$ & $\begin{array}{c}\text { Solo } \\
\text { instr./ } \\
\text { orch. ens. }\end{array}$ & $\begin{array}{c}\text { Genre } \\
\text { structure in } \\
\text { movements }\end{array}$ & Gene ral stylis tic obse rvations \\
\hline $\begin{array}{l}\text { Triple } \\
\text { Concerto/ } \\
\text { Concerto } \\
\text { for three }\end{array}$ & 1994 & $\begin{array}{l}\text { violin, } \\
\text { viola, } \\
\text { cello and } \\
\text { string } \\
\text { orchestra }\end{array}$ & $\begin{array}{l}\begin{array}{r}\text { I. Moderato } \\
\text { (Cello) }\end{array} \\
\text { II. Larghetto } \\
\text { (Viola) } \\
\text { III. Largo } \\
\text { (Violin) } \\
\text { IV. Allegro }\end{array}$ & $\begin{array}{l}\text { - it can hardly be considered a triple } \\
\text { concerto, because each movement is } \\
\text { dedicated to a single solo. } \\
\text { instrument, while the final mvt. is } \\
\text { designed as a sudden agglomeration } \\
\text { and explosion of energy. } \\
\text { - strong emphasis on timbral } \\
\text { peculiarities, looking for subtle } \\
\text { association between each soloist and } \\
\text { its correspondent section of the } \\
\text { string orchestra. } \\
\text { - each mvt. reveals an inner search } \\
\text { for order and finality, following the } \\
\text { timbre hierarchy (c ello-viola-violin) } \\
\text { - the musical disc ourse has a } \\
\text { constantly shifting evolution and } \\
\text { unstable structure. } \\
\text { - brief conclusion in the last mvt, } \\
\text { ferocius ending, superposition of } \\
\text { many musical layers and temporal } \\
\text { structures until the entire } \\
\text { accumulation of density collapses in } \\
\text { its own cluster of textures. }\end{array}$ \\
\hline
\end{tabular}

\section{Conclusions}

During the last two decades, Alfred Schnittke has been approached and analysed in doctoral researches, scientific papers (in different fields: philosophy, semiotics and even medicine) and also in many articles of musical journalism, emphasizing different aspects of his activity and creation. However, when searching scientific papers on this subject, we noticed a limited approach to his work and aesthetics, regarding polystylism and its connecttion with Schnittke's contribution. There is a tendency to disregard this concept, on the one hand because of its reception as artificial eclecticism, generating various collages without originality, and on the other hand due to the association of polystylism with the political regime imposed by the Soviet Union.

In conclusion, polystylism reveals itself as a reflexion of postmodernism in the musical field, on stylistical and aesthetical levels. In Schnittke's work, polystylism is not a museum of artifacts and historical exhibits, but a principle that generates vivid music, full of meaning and tonicity. Referring to the context in which Schnittke lived and activated, researcher Graham Freeman believes that his "polystylism is an aesthetic direction derived not from the postmodern 
proclivity towards pastiche and quotation, but is instead a narrative derived from the trauma, violence and opression of life in Soviet society. [...] In other words, polystylism is a musical manifestation of an aspect of the human condition that can be sublimated in many other artistic, cultural and linguistic products in the 20th century, ones with which Schnittke's musical aesthetic resonates closely" (Freeman, 2013, p. 50).

Polystylism, heteroclitical conception, polymorphic thinking and broad compositional horizon are the defining traits for perceiving Alfred Schnittke as a cosmopolitan creator, both geographically and historically - a composer of the world.

\section{References}

*** (2008). Dicţionar de termeni muzicali [Dictionary of Musical Terms], coordinated and edited by Gheorghe Firca. București: Editura Enciclopedica (article "Postmodern music", signed by Sandu-Dediu, V., pp. 443-444)

Andreica, O. (2012). Alfred Schnittke's Polystylistic Journey: the Third String Quartet. Studia Universitatis Babeş Bolyai - Musica, LVII, 1/2012, 103-115. ClujNapoca. Retrieved from:

http $/ /$ studia.ubbcluj.ro/arhiva/cuprins_en.php?id_editie=718\&serie=MUSICA\&nr=1 \&an $=2012$

Anghel, I. (1997). Orientări, direcţii, curente ale muzicii româneşti din a doua jumătate a secolului XX [Orientations, Directions, Tendencies of Romanian Music in the Second Half of the Twentieth Century]. București: Editura Muzicală.

Dixon, G. T. (2007). Polystylism as Dialogue: a Bakhtinian Interpretation of Schnittke's Symphonies No. 3, 4 and his Concerto Grosso No. 4/Symphony No. 5, $\mathrm{PhD}$ Thesis, Goldsmiths College. Retrieved from: https://www.academia.edu/9352943/Polystylism_as_Dialogue_A_Bakhtinian_Interpretation _of_Schnittkes_Symphonies_3_4_and_his_Concerto_Grosso_No._4_Symphony_No.5

Freeman, G. (2013). Alfred Schnittke and the Language of Trauma. In Postmodernism beyond the Iron Curtain: Alfred Schnittke's Work and Reception in the Context of East and Central European Music Discourses (Musicological Yearbook of the University of Music, Drama and Media) (pp. 49-60). Hannover: Hochschule für Musik, Theater und Medien Hannover. Retrieved from:

https://www.academia.edu/4176686/_Alfred_Schnittke_and_the_Language_of_Traum a._Postmodernism_beyond_the_Iron_Curtain._Hannover_Hochschule_f $\% \overline{\mathrm{C}} 3 \% \overline{\mathrm{BCr}}$ Musik_Theater_und_Medien_Hannover_HMTMH_2013_pp._49-60

Garaz, O. (2012). Muzica postmodernă: reinventarea artei muzicale după sfârşitul modernităţii [Postmodern Music: Reinventing Musical Art after the End of Modernity], in Muzica, No. 3/2012, 3-64. București: UCMR. Retrieved from: http:/www.ucmr.org.ro/Texte/RV-3-2012-1.pdf 
Ivashkin, A. (1992). The Paradox of Russian Non-Liberty. The Musical Quarterly, 76, 4, 543-556. Oxford, UK: Oxford University Press. Retrieved from: https://www.jstor.org/stable/742476

Ivashkin, A., \& Moody, I. (2001). Schnittke [Shnitke], Alfred. Grove Music Online. Retrieved 4 Sep. 2020, from:

https://www.oxfordmusiconline.com/grovemusic/view/10.1093/gmo/9781561592630. 001.0001/omo-9781561592630-e-0000051128

Ivashkin, A. - ed. (2002). A Schnittke Reader. Alfred Schnittke. Essays translated in English by John Goodliffe. Bloomington: Indiana University Press. Available on the web-site:https://books.google.ro/books?id=whaC9q-

$5 \mathrm{xGsC} \&$ printsec $=$ frontcover\&hl$=$ ro\&source $=$ gbs_ge_summary_r\& cad $=0 \# \mathrm{v}=$ onepage $\& \mathrm{q} \& \mathrm{f}=$ false

Jameson, F. (1984). Postmodernism, or the Cultural Logic of Late Capitalism. New Left Review, I/146 (July-August), 53-92. Retrieved from: https://pdfs.semanticscholar.org/40d6/b702fa28fdd1802abfb1210e10f1fa36de42.pdf

Kramer, J. (1996). Postmodern Concepts of Musical Time. Indiana Theory Review, vol. 17, No. 2. Bloomington, USA: Indiana University Press, 21-61. Retrieved from: http://www.jstor.org/stable/24044674

Miller, M. (1990). Schnittke - A Celebration. Tempo, 173, Soviet Issue, 66-68. Cambridge, UK: Cambridge University Press. Retrieved from: http://www.jstor.org/stable/946409

Moody, I. (1989). The Music of Alfred Schnittke. Tempo, 168, 4-11. Cambridge, UK: Oxford University Press. Retrieved from: www.jstor.org/stable/944851

Pasler, J. (2001). Postmodernism. Grove Music Online. Retrieved 4 Sep. 2020, from: https:/www.oxfordmusiconline.com/grovemusic/view/10.1093/gmo/9781561592630. 001.0001/omo-9781561592630-e-0000040721

Rice, H. C. (1989). Further Thoughts on Schnittke. Tempo, 168, 12-14. Cambridge, UK: Oxford University Press. Retrieved from: http://www.jstor.org/stable/944852

Ross. A. (1992). Connoisseur of Chaos. The New Republic, 28 Sept. Issue. Retrieved from: https:/alfredschnittke.wordpress.com/2010/05/18/connoisseur-of-chaos/

Ross, A. (1994). A Shy, Frail Creator of the Wildest Music, in New York Times, 10 Febr. Issue. Retrieved from: https://alfredschnittke.wordpress.com/2010/01/26/a-shyfrail-creator-of-the-wildest-music/

Ross, A. (1998). The Tragic Prankster. Obituary. In New Yorker, 7 Sept. Issue. Retrieved from: https://alfredschnittke.wordpress.com/2006/10/15/obituary-by-alexross/

Sandu-Dediu, V. (2004). Muzica nouă între modern şi postmodern [The New Music between Modern and Postmodern]. București: Editura Muzicală. 
Sangis, C. (2016). Alfred Schnittke on Polystylism. Some of Schnittke's thoughts on Polystylism in music extracted and analyzed. Bakersfield: California State University. Retrieved from: https://www.theodysseyonline.com/alfred-schnittke-polystylism

Schmelz, P. J. (2007). What Was 'shostakovich', and What Came Next?. Journal of Musicology, 24, 3, 297-338. Oakland, USA: University of California Press. Retrieved from: https://www.jstor.org/stable/10.1525/jm.2007.24.3.297

Scott, D. B. (2004). Postmodernism and Music. In The Routledge Companion to Postmodernism (pp. 122-32). Abingdon, UK: Routledge. Accesat pe: https://scholar.google.com/citations? user=L2UvKZsAAAAJ\&hl=en\#d=gs_md_citad $\& u=\% 2$ Fcitations $\% 3$ Fview_op $\% 3$ Dview_citation $\% 26 h 1 \% 3$ Den $\% 26$ user\%3DL2UvKZ sAAAAJ\%26citation_for_view\%3DL2UvKZsAAAAJ\%3AK1AtU1dfN6UC\%26tzom $\% 3 \mathrm{D}-180$

Searle, A. (2001). Voices in the dark. The Guardian, 12 January Issue. Retrieved from: https://alfredschnittke.wordpress.com/2010/04/30/voices-in-the-dark/

Tremblay, J. B. (2007). Polystylism and Narrative Potential in the Music of Alfred Schnittke (PhD Thesis. Vancouver, Canada: University of British Columbia). Retrieved from: https://open.library.ubc.ca/cIRcle/collections/ubctheses/831/items/1.0100526

Webb, J. (1992). Schnittke in Context. Tempo, 182, Russian Issue, 19-22. Cambridge, UK: Cambridge University Press. Retrieved from: https://www.jstor.org/stable/946100 